\title{
Evaluation of Rain Water Harvesting Systems for coping water shortage in the Upper Blue Nile Basin, North West Ethiopia
}

Amare Tsige genet ( $\nabla$ amaretsigegenet@gmail.com )

Amhara Regional Agricultural Research Institute https://orcid.org/0000-0002-7448-3362

\section{Ataklite Abebe}

Amhara Regional Agricultural Research Institute

\section{Dires Tewabe}

Amhara Regional Agricultural Research Institute

\section{Alebachew Enyew}

Amhara Regional Agricultural Research Institute

Research

Keywords: Pond, optimization, performance efficiency, water scarcity and water shortage

Posted Date: July 23rd, 2021

DOI: https://doi.org/10.21203/rs.3.rs-720331/v1

License: (c) (i) This work is licensed under a Creative Commons Attribution 4.0 International License. Read Full License 


\section{Abstract \\ Background}

The applicability of rainwater harvesting structure is very poor while the intended purpose is achievable in the Blue Nile basin. Therefore, this research was initiated to evaluate the performance of a rainwater harvesting structure and put possible strategies for dry season challenges. The study carried out for three years in the North West Ethiopia.

\section{Methods}

The data were analyzed using daily water balance model and other performance indicators (number of water day, relative irrigation supply, runoff storage efficiency and marginal rate of return).

\section{Results}

At the inception, it was established that the existing rain water harvesting system performs very low, runoff storage efficiency below $46 \%$, no zero water day above $50 \%$, relative irrigation supply below $27 \%$ and marginal rate of return from 12 to $65 \%$. However the greater the volume of the rain water harvesting structure the higher runoff storage efficiency, higher relative irrigation supply, and lower no water day under different irrigation technique was achieved.

\section{Conclusions}

For attaining household irrigation water demand in the dry season, the user should adopt storage capacity of $630 \mathrm{~m}^{3}$ in Nitisol and $361 \mathrm{~m}^{3}$ in Vertisol for double cropping and $273 \mathrm{~m}^{3}$ in Rigosol for supplemental irrigation. Hence, applying rainwater harvesting technologies with efficient water management technique enhance the net benefit of the system.

\section{Background}

Most rural households in Ethiopia, especially in the Upper Blue Nile basin, depend on rain-fed agriculture for their livelihoods (Yesuf Abdella et al., 2020). The agricultural productivity in the region is constrained by climate change (Deressa and Hassan, 2009) and land degradation (Teka $\mathrm{K}$ et al., 2015). Climate change is already happening, with multi-faceted effects on human being and the ecosystem (Gomoro, 2014). The rainfall variability in the region is a high coefficient of variation (CV) ranges 20 to 40 (Mekonnen et al. 2012; Amare et al. 2018).

Access to water provides a basis for human livelihoods, culture, and progress (Smit and Wandel, 2006). Adams et al. (2009) and Smith et al. (2009) found that water stress undermines societies' place-specific livelihood systems and strategies that, in turn, induce new patterns of human migration (Black et al., 2011). Water scarcity can mean scarcity in availability due to physical shortage, or scarcity in access due to the failure of institutions to ensure a regular supply or due to a lack of adequate infrastructure (UN water 2018). As many of developing countries, the increasing population, improving living standards, unplanned migration, rising of temperature, and expansion of irrigated agriculture are the main driving forces for the rising of human demand for water (Ercin et al., 2014) This water scarcity result in declining subsistence agricultural production may accelerate migration patterns (Nawrotski and Bakhtsiyarava, 2017).

In Ethiopia, the drought occur once every three or four years due to various reasons (Fentaw 2011) and drought occurred between 1965 and 2008 affected about 54 million people (EM-DAT 2010). These extreme events result in economic losses and negative impacts on ecosystems and human health (Mulatu, et al. 2016). Moreover, $40 \%$ of the population living below the national poverty line (Yesuf Abdella et al. 2020). Besides the average adoption rate of water harvesting technology is as high as 22-42\% in the regional as well as in the national level (Begashawe 2005; Mekonnen et al. 2012). The major factors 
are funding, material availability, potential sites for disease, high water loss to seepage and evaporation and limited technical design capacity and irrigation calendar skills ( Begashawe 2005; Mekonnen et al. 2012; Teka K 2018).

The rainwater harvesting system incorporated technical components to ensure good harvested water quantity, and water-level monitoring system. Performance assessment parameters - no water days (NWDs), rainwater storage efficiency (RSE), relative irrigation supply (RIS), marginal rate of return (MRR) and water level in storage pond (WL) were defined and used. However, the system was inadequate because water users suffered for several days without water during the dry season. In an attempt to minimize NWDs and increasing RIS and RSE using the existing system, a socio-technical strategy with variable demand application was introduced (Mwamila et al. 2015). Despite the strategy's potential in some demand scenarios, demand still pose a challenge for this technology and daily water demand is hard to meet. Therefore, this research initiated to evaluate the performance of rainwater harvesting system and put possible strategies in the study area.

\section{Materials And Methods}

\section{Description of the Study area}

The study conducted in the upper Blue Nile basin, Northwest Ethiopia. The rainfall pattern is unimodal regime, while the rainy season runs from April to October in the South West and June to September in the North East (Bekele 1997). The mean annual rainfall estimated between 800 to $1600 \mathrm{~mm}$, with $74 \%$ in the four wet months of June to September (Figure 1). The topography is very complex, with elevation ranging from $500 \mathrm{~m}$ in the lowlands at the Sudan border to $4160 \mathrm{~m}$ in the upper parts of the basin. The basin has five major soil groups, Nitisols, Leptosols, Luvisols, vertisols, cambisols, Alisols, Phaeozems, Regosols and Fluvisols (TekluErkossa,2009).

\section{Data collection}

Primary and secondary data were collected from different district through questionnaires, group discussion, and field observation. Besides the functionality of the structure was categorized based on fulfillment of pre-defined purposes, having near-optimal functionality, maintaining acceptable safety, economically justifiable and met environmental, legal, social, and other relevant requirements Table 1. Moreover, the selection of experimental rainwater harvesting structure was done based on rainfall pattern, soil types, road accesses and functionality of the structure. Measurements of water input and output (abstraction, rainfall, runoff, evaporation and seepage) from the storage were measures following international standards.

Table 1. Status of rainwater harvesting systems (RWHS)

\begin{tabular}{|c|c|c|c|c|c|c|c|c|}
\hline \multirow{2}{*}{$\begin{array}{l}\text { Types of } \\
\text { the pond }\end{array}$} & \multirow{2}{*}{$\begin{array}{l}\text { Number } \\
\text { of } \\
\text { structure }\end{array}$} & \multirow{2}{*}{$\begin{array}{l}\text { Fulfillment } \\
\text { of } \\
\text { intended } \\
\text { purpose }\end{array}$} & \multirow{2}{*}{$\begin{array}{l}\text { Functionality } \\
\text { (\%) }\end{array}$} & \multirow{2}{*}{$\begin{array}{l}\text { Non- } \\
\text { functional } \\
(\%)\end{array}$} & \multirow{2}{*}{$\begin{array}{l}\text { economical } \\
\text { justifiable }\end{array}$} & \multicolumn{3}{|c|}{ maintain ELS status } \\
\hline & & & & & & Environment & Legal & social \\
\hline $\begin{array}{l}\text { Trapezoidal } \\
\text { /plastic } \\
\text { lined/ }\end{array}$ & 19 & No to little & 47.4 & 52.6 & No & moderate & moderate & No \\
\hline $\begin{array}{l}\text { Trapezoidal } \\
\text { /unlined/ }\end{array}$ & 89 & No to little & 7.9 & 92.1 & No & moderate & moderate & No \\
\hline $\begin{array}{l}\text { Circular } \\
\text { /cemented }\end{array}$ & 9 & No & 0 & 100 & No & moderate & moderate & No \\
\hline Total & 117 & & & & & & & \\
\hline
\end{tabular}

\section{Data type and source}

The basic parameters adopted for performance evaluation of the RWH system included a storage volume of $129 \mathrm{~m}^{3}$, irrigable land of $200 \mathrm{~m}^{2}$, average landholding size of $2000 \mathrm{~m}^{2}$ and catchment area less than200 m² (mixed 
land use type), a runoff coefficient of 0.56 . ETo, water level and irrigation demand data were used as shown from Figure 2 and 3 .

Irrigation demand estimated using the CROPWAT 8.0 model. All calculation procedures used in CROPWAT 8.0 are based FAO No. 56 and No. 33. Then the generated crop water and irrigation requirements values under furrow irrigation shown in Figure 4 and Table 2. At the inception full irrigation was given for all treatments to create favorable environment of the crop root distribution and emergency.

\section{Data analysis}

The analysis was performed using a simple daily water mass balance model with an overall cumulative water storage Equation (1). This incorporates the performance parameters both for a dry spell and dry season quantification, NWD, RSE ,and RIS (Mwamila et al. 2015) (Equations (2)-(4)).

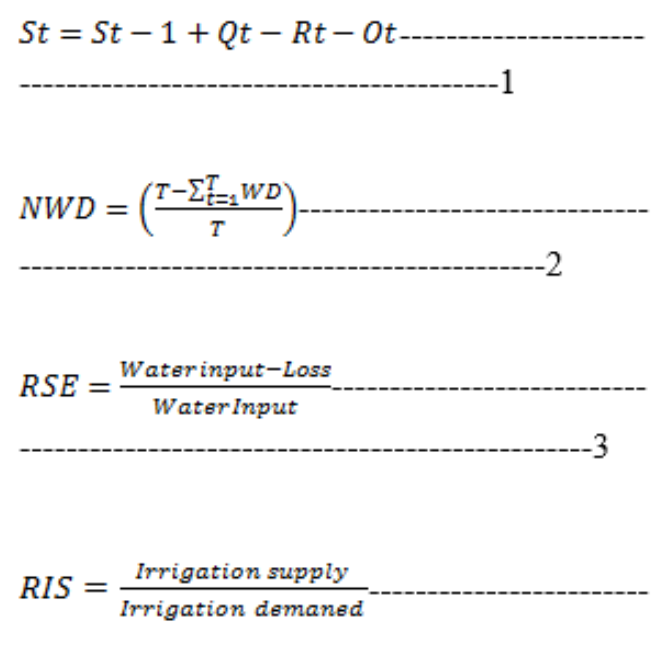

4

Where: St- 1 is storage at end of previous time interval $\left(\mathrm{m}^{3}\right)$, St is storage at end of current time interval $\left(\mathrm{m}^{3}\right)$, Qt is inflows at a current time interval $\left(\mathrm{m}^{3}\right)$, Rt is release at a current time interval $\left(\mathrm{m}^{3}\right)$, and Ot is loss (evap/seepage) at current time interval $\left(\mathrm{m}^{3}\right)$, NWD is number of water day, WD is the number of irrigation day on which the demand is fully met; $T$ is the total number of irrigation days in the season, RSE: Runoff storage efficiency, and RIS Relative irrigation supply.

The analytical method considers variable daily demand scenarios for both rainfall pattern (Table 2). Variable demand, based on water resource reliability, apply using deficit irrigation technique is a novel approach devised by (Moshel and Mikael 1995). The treatment was set based on the previous findings of regulated deficit and alternative furrow irrigation merit. Regulated deficit irrigation strategies reduced actual crop evapotranspiration by 2-27\% (HuiyingYang et al. 2018) and alternate furrow irrigation method saved 33 to $50 \%$ of water as compared with every furrow irrigation (Eba AT2018). Besides, the treatment setup considers the allowable depletion level of hot peeper, $30 \%$. This approach is a better strategy for water stress area.

The performance of a system usually measured using its efficiencies, operational methods, and construction cost. It was carried out for both the existing system and the consideration of additional systems in the community.

Table 2.Irrigation water requirement for different irrigation method 


\begin{tabular}{llll} 
Irrigation depth & Nitisol (mm) & $\begin{array}{l}\text { Vertisol } \\
(\mathrm{mm})\end{array}$ & $\begin{array}{l}\text { Rigosol } \\
(\mathrm{mm})\end{array}$ \\
\hline Full irrigation (conventional furrow) & 582 & 362 & 285 \\
\hline $80 \%$ ETc (Regulated deficit irrigation) & 500 & 304 & 228 \\
\hline $60 \%$ Etc (Alternative furrow irrigation) & 418 & 246 & 171
\end{tabular}

Table 3.RWHs investment cost

a)high rainfall pattern

\begin{tabular}{|c|c|c|c|c|c|}
\hline & $\begin{array}{l}\text { Catchment } \\
\text { size_( }\left(m^{2}\right)\end{array}$ & $\begin{array}{l}\text { Irrigable } \\
\text { land }\left(\mathrm{m}^{2}\right)\end{array}$ & $\begin{array}{l}\text { Rainwater harvesting } \\
\text { structure size_ }\left(\mathrm{m}^{3}\right)\end{array}$ & $\begin{array}{l}\text { Construction cost } \\
\text { (Ethiopian Birr) }\end{array}$ & Remark \\
\hline Plastic lined(Niti sol) & $<300$ & 125 & 129 & 35966 & $\begin{array}{l}\text { Existing } \\
\text { case }\end{array}$ \\
\hline Unlined(Verti sol) & $<300$ & 150 & 129 & 19791 & $\begin{array}{l}\text { Existing } \\
\text { case }\end{array}$ \\
\hline $\begin{array}{l}\text { Plastic lined ( } 40 \% \text { deficit } \\
\text { Niti/verti sol) }\end{array}$ & $>1000$ & $1550 / 1676$ & $669 / 367$ & $167250 / 91750$ & $\begin{array}{l}\text { Proposec } \\
\text { case }\end{array}$ \\
\hline $\begin{array}{l}\text { Plastic lined ( } 20 \% \\
\text { deficitNiti/verti sol) }\end{array}$ & $>1500$ & $1507 / 1639$ & $800 / 453$ & $200000 / 113250$ & $\begin{array}{l}\text { Proposec } \\
\text { case }\end{array}$ \\
\hline $\begin{array}{l}\text { Plastic lined (Full } \\
\text { irrigation Niti/verti sol) }\end{array}$ & $>2000$ & $1471 / 1600$ & $931 / 540$ & $232750 / 135000$ & $\begin{array}{l}\text { Proposec } \\
\text { case }\end{array}$ \\
\hline
\end{tabular}

b) Low rainfall pattern

\begin{tabular}{|llllll|}
\hline & $\begin{array}{l}\text { Catchment } \\
\text { size }\left(\mathrm{m}^{2}\right)\end{array}$ & $\begin{array}{l}\text { Irrigable } \\
\text { land }\left(\mathrm{m}^{2}\right)\end{array}$ & $\begin{array}{l}\text { Rainwater harvesting } \\
\text { structure size }\left(\mathrm{m}^{3}\right)\end{array}$ & $\begin{array}{l}\text { Construction cost } \\
\text { (Ethiopian Birr) }\end{array}$ & $\begin{array}{l}\text { Remark } \\
\text { Plastic lined }\end{array}$ \\
$>1000$ & 200 & 129 & 35966 & $\begin{array}{l}\text { Existing } \\
\text { case }\end{array}$ \\
\hline unlined & $>1000$ & 200 & 129 & 19791 & $\begin{array}{l}\text { Existing } \\
\text { case }\end{array}$ \\
\hline $\begin{array}{l}\text { Plastic lined (40\% } \\
\text { deficit) }\end{array}$ & $<1500$ & 1804 & 171 & 42750 & $\begin{array}{l}\text { Proposed } \\
\text { case }\end{array}$ \\
$\begin{array}{l}\text { Plastic lined (20\% } \\
\text { deficit) }\end{array}$ & $1500-2000$ & 1744 & 273 & 68250 & $\begin{array}{l}\text { Proposed } \\
\text { case }\end{array}$ \\
\hline $\begin{array}{l}\text { Plastic lined (Full } \\
\text { irrigation) }\end{array}$ & $>2000$ & 1676 & 399 & 99750 & $\begin{array}{l}\text { Proposed } \\
\text { case }\end{array}$ \\
\hline
\end{tabular}

\section{Results And Discussion}

\section{Performance evaluation of the existing RWH system}

The existing system showed poor performance in both parameters under any of the scenario (Figure 4). Unlike the common sense runoff storage efficiency in vertisol was as high as 0.46 percent while plastic-lined rainwater harvesting structure performs well above 0.70 . The major reasons for the low storage performance of vertisol are evaporation and seepage loss. 
It shares $6.5 \%$ evaporation and $40 \%$ seepage from the total harvested water. Consequently, reduce irrigable land by $33.4 \%$. Reduce the loss by possible mechanisms is very important. The finding is in close agreement with Amare et al. (2018) and Eyasu et al. (2006) who reported protecting the net harvested water from evaporation and seepage loss by shade and lining material save water for irrigation operation.

As shown in Figure 4. All performance indicator parameters perform poorly. Runoff storage efficiency for unlined vertisol is very low (45\%) unlike the plastic lined pond(70-74\%) and the common sense of vertisol water holding capacity. Besides, the relative irrigation supply gives 16 to $27 \%$ while expecting 70 to $100 \%$ (Mwamila et al. 2015). No water day contains 40 to $80 \%$ while expecting approach to zero (Mwamila et al. 2015). This implies the planning was poor. The result concedes with the finding of MoARD (2000), Begashawe (2005), Mekonnen et al. (2012),Teka K(2018), who reported diversity and economics is not well taken into account when a program is designed

\section{Performance evaluation of extending rainwater-harvesting technology}

To promote and uphold the efficiency and effectiveness of a system, graphical extrapolation was done until relative irrigation supply approach to one and no water day approach to zero as shown in (Figure 5). The graph serves as a menu to design the program considering diversity, economics and operation scenario.

When an attempt was made to reduce NWD and increase RIS, 42,68 and $100 \%$ RIS with uniform zero water day for Alternative furrow irrigation, regulated deficit irrigation and full irrigation was achieved respectively. The implementation cost is 4.6 to 6.8 times that of the existing system. The finding is in line with Mwamila (2016), the implementation cost increase more than four times as RIS goes to one and NWD to zero.

Plastic lined vertisol shows higher RIS and low initial investment cost than plastic-lined Nitisol. This is due to the water holding capacity of irrigable land. Tesfaye et al. (2018) reported similarly, irrigation requirement for pepper in vertisol is much less than nitisol.

\section{Proposed strategies to mitigating water shortages for the dry season and dry spell}

The simulation model runs for different degree of water availability to a given crop. The result showed that as the availability of irrigation water increases, the yield also increases while water resource availability increment above 75\% (nitisol), $80 \%$ (Vertisol) and $66.7 \%$ (Rigosol) the rate of increment in yield was insignificant. Thus the optimum reservoir size, relative irrigation supply, marginal rate of return and irrigable area were determined using water balance principle under normal rainfall year (Table 4).

Table 4.Optimization values

\begin{tabular}{|c|c|c|c|c|c|}
\hline irrigation type & $\begin{array}{l}\text { soil } \\
\text { type }\end{array}$ & $\begin{array}{l}\text { Rainwater harvesting structure } \\
\text { size }(\mathrm{m} 3)\end{array}$ & $\begin{array}{l}\text { Relative irrigation } \\
\text { supply (\%) }\end{array}$ & $\operatorname{MRR}(\%)$ & $\begin{array}{l}\text { Irrigable } \\
\text { area(m2) }\end{array}$ \\
\hline \multirow[t]{3}{*}{ Double cropping } & Nitisol & 630 & 75 & 127.4 & 1500 \\
\hline & Vertisol & 361 & 80 & 230.7 & 1600 \\
\hline & any & 129 & 18 & 12 & 250 \\
\hline \multirow{2}{*}{$\begin{array}{l}\text { Supplemental } \\
\text { irrigation }\end{array}$} & Rigosol & 273 & 67.7 & 124 & 1744 \\
\hline & any & 129 & 27 & 65 & 1530 \\
\hline
\end{tabular}

Despite the optimal value, the construction cost per irrigated land was extremely high; it was as high as 541500 to 1177500 birr ha ${ }^{-1}$ for planed irrigable land in the humid area. However, the cost/ha for river diversion and storage dams in Amhara region and East Africa range was70,000 to 120,000 and 250,000 to 400,000 respectively (BOA, 2019; Inocencio A et al. 2007). 
Therefore, it was wise to give priority to alternative irrigation technologies based on the water resource available instead of constructing the same type of systems all over the region.

\section{Conclusion}

The status and adoption rate of rainwater harvesting system in the upper Blue Nile basin is very poor against the intended purpose of increasing crop production, productivity and thereby improve the socio-economic standard of the society. The existing rainwater-harvesting system showed poor performance in both parameters under any of the scenarios. Increasing the volume of rain water harvesting structure and applying deficit irrigation technique improve the performance parameters; relative irrigation supply and runoff storage efficiency to one and no water day to zero and reasonable marginal rate of return. Thus to mitigate water shortage the society should adopt a size of $630 \mathrm{~m}^{3}$ (Nitisol) and $361 \mathrm{~m}^{3}$ (vertisol) for double cropping and $273 \mathrm{~m}^{3}$ (Rigosol) for supplemental irrigation.. Moreover, the study reveals that the rainwater harvesting system is economically viable in the study area. The simulation test and analysis described in this study based upon the main assumption of flow and demand will repeat them in the future. The performance of the system can be improved by monitoring water levels and adhering to demand and supply guidelines.

\section{Declarations}

\section{Acknowledgement}

The Amhara Agricultural Research Institute (ARARI) is gratefully acknowledged for fnancing this research. We deeply appreciate and acknowledge Adet Agriculture research staff for their assistance in implementing the fieldwork.

Authors' contributions: AT,AA,DT conceptualized this study, AT,AA,DT and AE collects necessary data, AT analyzed, interpreted the data, and wrote the manuscript. All authors read and approved the final manuscript.

Funding: This study received no external funding.

Availability of data and materials: can access from the corresponding author upon request.

Ethics approval and consent to participate: Not applicable.

Consent for publication: Not applicable.

Competing interests: The authors declare no competing interests.

\section{References}

Adams H.D, GuardiolaClaramonte M, BarronGafford GA, Villegas JC, Breshears DD, Zou CB \&Huxman TE, (2009). Temperature sensitivity of droughtinduced tree mortality portends increased regional die-off under global-change-type drought. Proceedings of the National Academy of Sciences, 106(17): 7063-7066

Amare Tsige Genet, Seifu Admassu and Mesenbet Yibeltal ( 2018). Optimal Sizing of On-Farm Rain Water Harvesting Structure for Supplemental Irrigation. Blue Nile Journal of Agricultural Research.Vol 1, No 1, 2018.

BegashawMollaTeshome (2005). Evaluation of rainwater harvesting systems in Amhara Region: A case study in LiboKemkemWoreda. A Master Thesis submitted to school of graduate study, Alamaya University, Ethiopia.

Bekele F (1997). "Ethiopian use of ENSO information in its seasonal forecasts," Internet Journal of African Studies: http://ccb.colorado.edu/ijas/ijasno2/bekele.html 
Black R, Bennett SR, Thomas SM, \& Beddington JR, (2011). Climate change: Migration as adaptation. Nature, 478(7370): 447-449.

BOA (2019). Bureau of Agriculture annual reports, Unpublished report.

Deressa TT and Hassan MR, (2009). "Economic Impact of Climate Change on Crop Production in Ethiopia: Evidence from Cross-section Measures." Journal of African Economies 18(4): 529-554

Eba AT(2018). The Impact of Alternate Furrow Irrigation on Water Productivity and Yield of Potato at Small Scale Irrigation, Ejere District, West Shoa, Ethiopia. J Plant Sci Agric Res. Vol.2 No.2:16

Ercin AE, Hoekstra AY,(2014). Water footprint scenarios for 2050: A global analysis. Environment International 64, 71-82

EyasuYazawa, Girmay G/Samuela, FitsumHagos, Gideon Krusemanc, Vincent Linderhofd, MekonenYohannese, Afeworki Mulugeta and ZenebeAbreha, (2006). Water Harvesting for Poverty Reduction and Sustainable Resource Use: Environment and technical issues. PREM working paper. Online www.prem-online.org (Accessed April-17, 2019)

EM-DAT. (2010). “Data Resources: Ethiopia - DSS.” Retrieved December 11, 2017, 2017, from dss.princeton.edu/cgibin/dataresources/newdataresources.cgi?term=109.(accessed 15 Jan. 2020)

Fentaw AE (2011). Impacts of Climate Variability and Change on Food Security and Farmers' Adaptation Strategies in GubalaftoWoreda, north Wollo, Ethiopia.M.Sc., Addis Ababa University.

Gomoro G (2014). Local People's Perception on Climate Variability, Its Impact on their Livelihoods and Adaptation Measures in WelisoWoreda, Oromia Regional State. , Haramaya University

Inocenci A, Kikuchi M, Tonosaki M, Maruyama A, Merrey D, Sally H, de Jong I. (2007). Costs and performance of irrigation projects: A comparison of sub-Saharan Africaand other developing regions. Colombo, Sri Lanka: International Water Management Institute. 81 pp. (IWMI Research Report 109)

Mekonnen B. Wakeyo 2012. Economic Analysis of Water Harvesting Technologies in Ethiopia, 164 pages PhD thesis, Wageningen University, Wageningen, NL (2012) With references, with summaries in English and Dutch. ISBN 978-94-6173-870-7

Ministry of Agriculture and Rural Development/MoARD (2000). Agro-ecological Zonations of Ethiopia, Addis Ababa, Ethiopia Mohammed Abdelmahmood El shikh, Haitham R. Elramlawi, and Hassan I. Mohamed ,(2015). Water balance Simulation Model for Optimal Reservoir Sizing and Multi-crop Cultivation Area for Small Scale Water Harvesting in rainfed farming System at Khor Abu Farga - Gadarif - Sudan. International Conference on Chemical, Environmental and Biological Sciences (CEBS-2015) March 18-19, 2015 Dubai (UAE).http://dx.doi.org/visited

MoshelFinkel and Mikael, (1995). Water harvesting, proceeding of the SADC-ELMS Practical Workshop (10_ 28 May,1993), Namibia. pp 2-5

Mulatu DW, Eshete ZS and Gatiso TG, (2016). The Impact of CO2 Emissions on Agricultural Productivity and Household Welfare in Ethiopia: A Computable General Equilibrium Analysis: 27.

Mwamila TB, Moo Young Han, Preksedis Marco Ndomba and ZachariaKatambara,(2016). Performance evaluation of rainwater harvesting system and strategy for dry season challenge. Water Practice \& Technology Vol 11 No 4 . doi: 10.2166/wpt.2016.090

Mwamila TB, Han MY, Kim T I \&Ndomba PM, (2015). Tackling rainwater shortages during dry seasons using a sociotechnical operational strategy. Water Science \& Technology: Water Supply 15 (5), 974-980.

Page 8/12 
Raphael J. Nawrotzkia and MaryiaBakhtsiyaravab 2017. International Climate Migration: Evidence for the Climate Inhibitor Mechanism and the Agricultural Pathway. Popul Space Place. 2017 May ; 23(4): . doi:10.1002/psp.2033.

Smith JB, Schneider SH, Oppenheimer M, Yohe GW, Hare W, Mastrandrea MD \&Füssel HM, (2009). Assessing dangerous climate change through an update of the Intergovernmental Panel on Climate Change (IPCC) "reasons for concern". Proceedings of the National Academy of Sciences, 106(11): 4133-4137

Smit B \& Wandel J, (2006). Adaptation, adaptive capacity and vulnerability. Global Environmental Change, 16(3): $282-292$.

Teka K (2018). Household level rainwater harvesting in the drylands of northern Ethiopia: its role for food and nutrition security AgriFoSe2030 reports 11, 2018 ISBN: 978-91-576-9598-7

Teka KA, VanRompaey J, Poesen S, Van Bruyssel J, Deckers and Amare K, (2015). "Spatial Analysis of Land Cover Changeds in Eastern Tigray (Ethiopia) from 1965 to 2007: are there signs of a Forest Transition?" Land Degradation and Development 26: 680-689

Teklu Erkossa, Seleshi Bekele Awulachew, Amare Haileslassie and Aster DenekewYilma, (2009). Impacts of Improving Water Management of Smallholder Agriculture in the Upper Blue Nile Basin.SourceRePEc. Project: African and South Asian livestock water productivity project

Tesfaye Feyisa,Tadele Amare and Mulugeta Alemayehu(eds.), (2018). Proceedings of the 2nd'and 3rd'Annual Regional Conferences on Completed Research Activities on Agricultural Water Management, January22 to February 1, 2013 and October27-to-November2, 2014, Amhara Agricultural Research Institute (ARARI), Bahir Dar, Ethiopia. ISBN- 978-99944-927-7-0. Published in 2018

Thomas TH. \& Martinson DB, (2007). Roofwater Harvesting: A Handbook for Practitioners. IRC International Water andSanitation Centre, Delft, The Netherlands

UN water (2018). Water fact- water scarcity. https://www.unwater.org > app > uploads > 2018/10. (Accessed 7 July 2021).Yang Huiying, Liu Hai-Jun, Zheng Jianhua, Huang Quanzhong 2018. Effects of regulated deficit irrigation on yield and water productivity of chili pepper (Capsicum annuum L.) in the arid environment of Northwest China. Irrigation Science @ SpringerVerlag GmbH Germany, part of Springer Nature 2017. https://doi.org/10.1007/s00271-017-0566-4

YesufAbdella, Zelalem Tadesse, SemuMogus, DemelashGetachew, MulatDemeke, and Samson Desie, (2020). Concerns on the ongoing negotiation of grand Ethiopia renaissance dam (GERD) - February 2020, Nairobi. un published document.

\section{Figures}




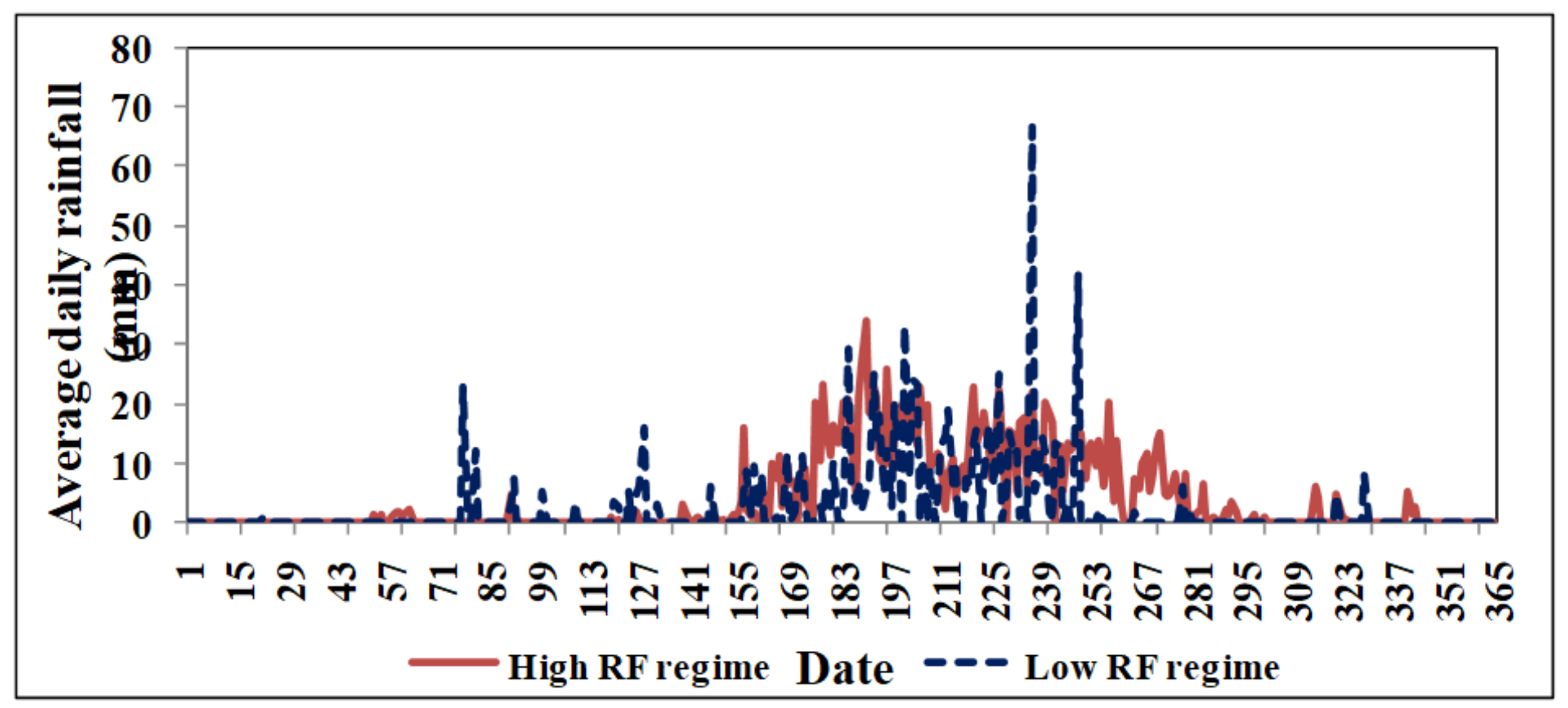

Figure 1

Rainfall pattern of the study area

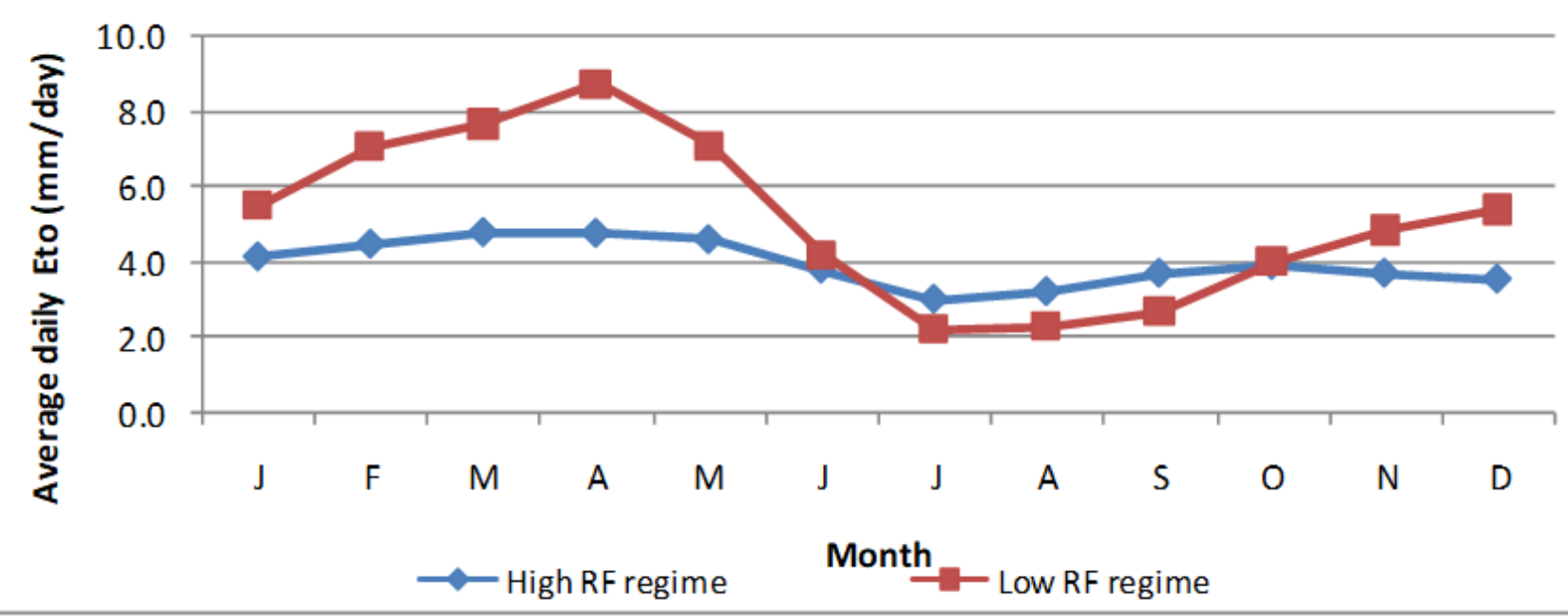

Figure 2

Reference evapotranspiration pattern of the study area 


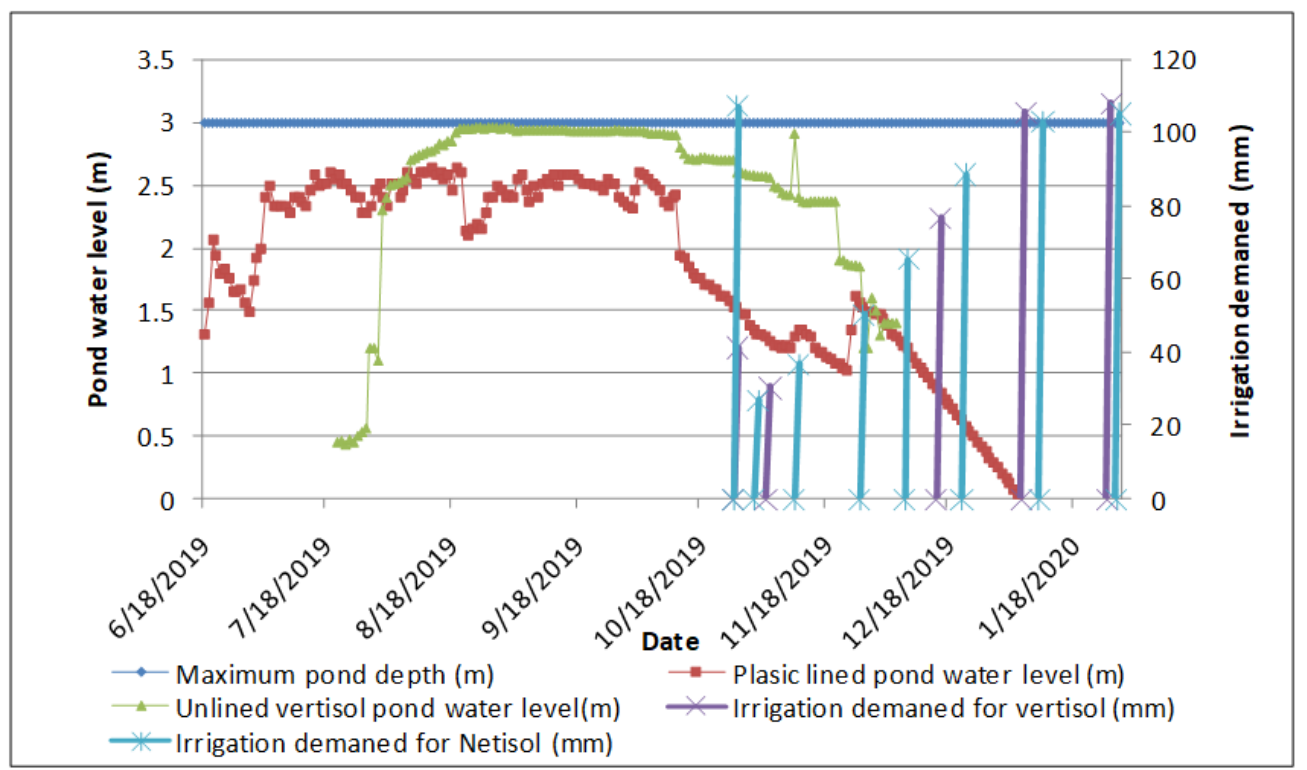

a) high rainfall regime

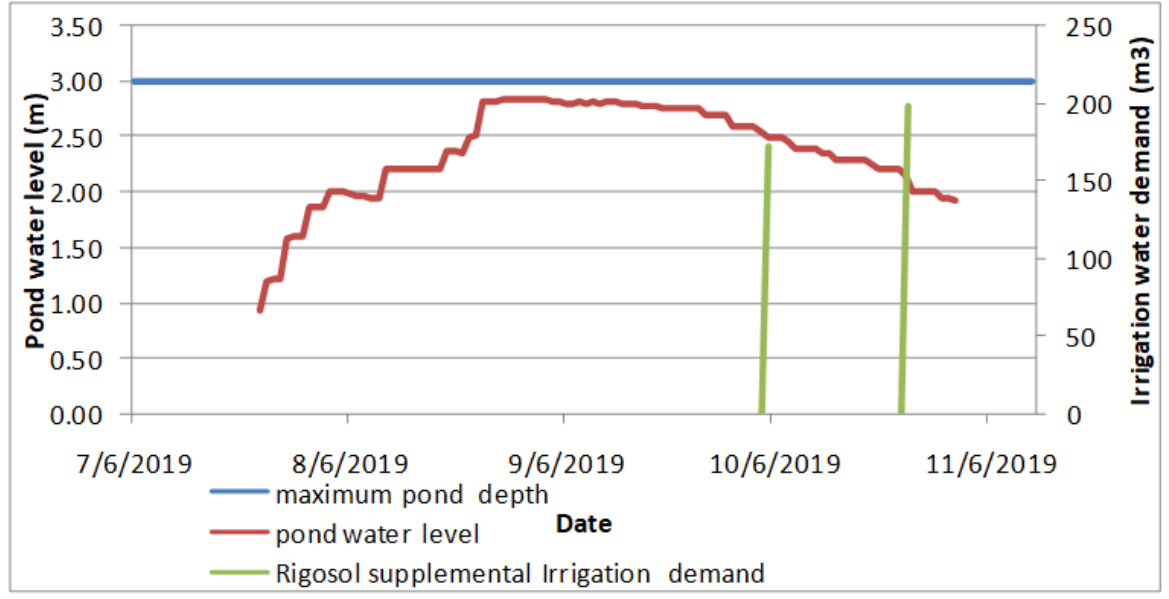

b) Low rainfall regime

\section{Figure 3}

rain water harvesting structure Water level and irrigation demand of the study area 


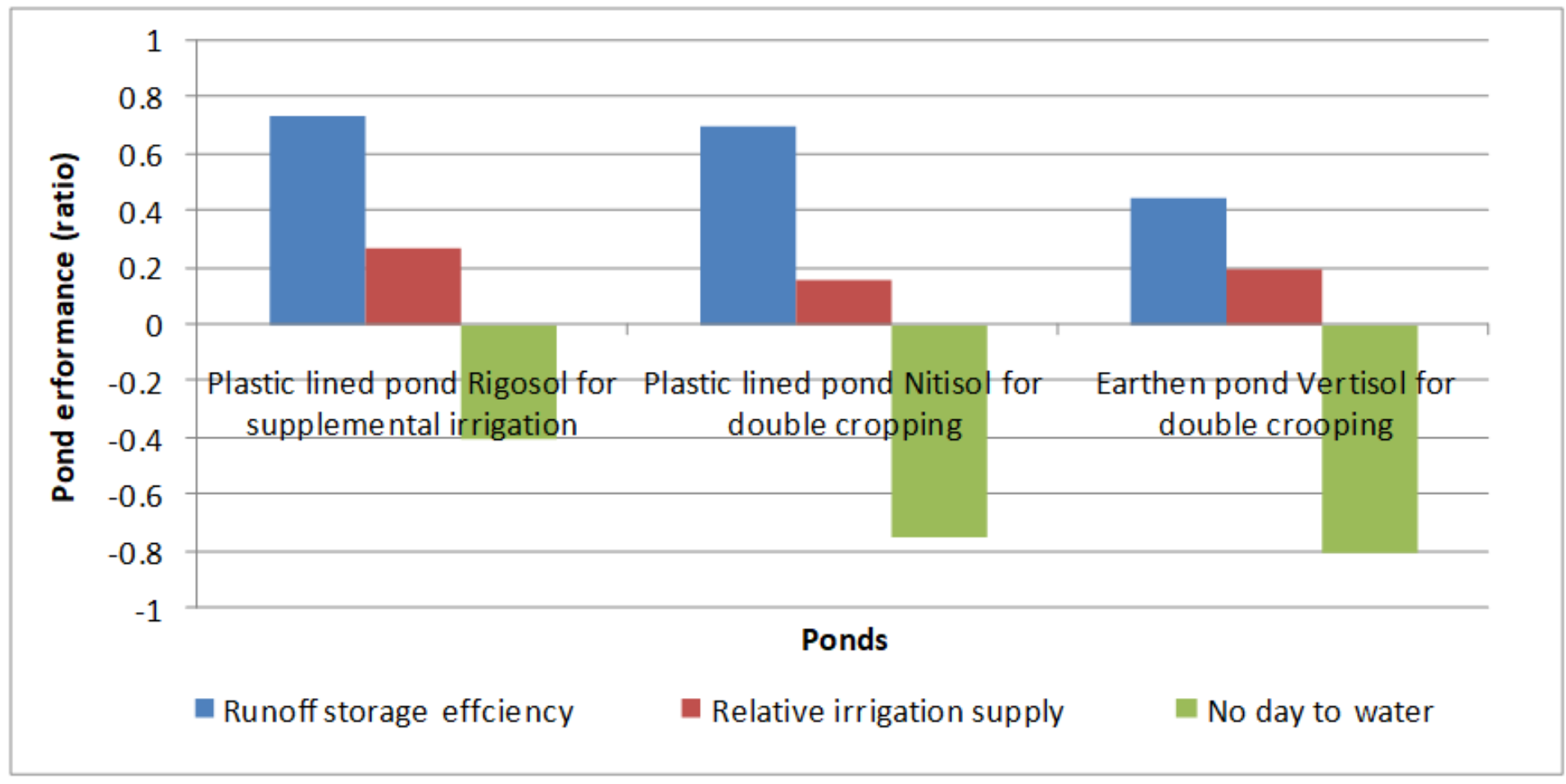

Figure 4

Average performance efficiency on rainwater harvesting systems

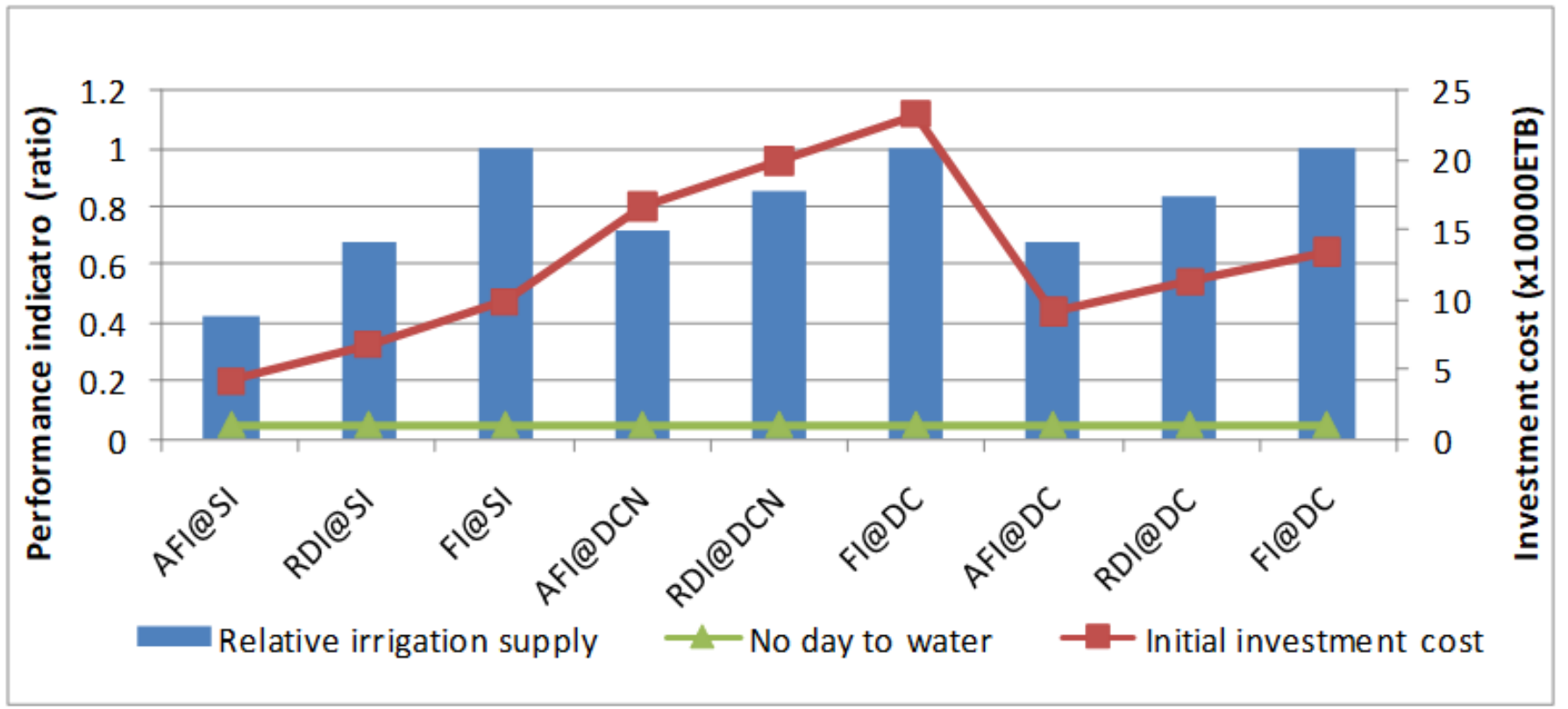

Figure 5

Performance of proposed RWHs with cost implication 